Effect of Financial Performance and Good Corporate Governance of Bond Ratings (A

Case Study Companies Listed In Indonesia Stock Exchange Period 2013-2017)

\title{
Effect of Financial Performance and Good Corporate Governance of Bond Ratings (A Case Study Companies Listed In Indonesia Stock Exchange Period 2013-2017)
}

\author{
Dina Esensia ${ }^{1 *}$, Ahmad Fauzan Fathoni ${ }^{2}$, and Haryetti ${ }^{3}$ \\ 1, 2,3 Universitas Riau, Pekanbaru, Indonesia
}

\begin{abstract}
One type of investments that are considered safe and profitable is a bond. However, this investment has a risk of the company in the form of debt default risk will also affect investor decisions. Therefore, investors need to know the potential risks to be faced with analyzing the viability of the company that became a place for investment by bond rating. In addition, investors need to see whether companies apply corporate governance (GCG) or not because by implementing good corporate governance (GCG) in the company reflects that the company is able to manage efficiently the company's financial performance, including managing the assets and returns. This study aims to examine how the influence of the financial performance and good corporate governance on bond ratings. The population in this study is a company that was listed on the Indonesia Stock Exchange in 2013-2017 as many as 555 companies with a total sample of 57 companies,Sampling technique used is purposive sampling method methods of analysis used in this study is the logistic regression analysis and the results showed that financial performance variables significant negative effect on obigasi ranked. While good corporate governance variables were significant positive effect on bond ratings.
\end{abstract}

Keywords: Bond Rating, GCG, Return On Assets.

\section{Introduction}

Amid global competition at the moment, many companies require funding in developing a business so the company must publish the value of the securities as a contributing factor. According Ginting (2012), sources of funding can be obtained from the company (internal financing) and outside financing (external financing). Internal funding sources obtained from the use of retained earnings that undistributed profits to dividends. While external funding of the loan obtained by the company to outside parties to sell shares to issue bonds in the capital market. The reason why many companies issued bonds are as one form of corporate funding to finance investment. Investments in bonds is one of the most attractive investment by the investor. This is because the bonds have a fixed income earned from interest to be received on a periodic basis and principal at maturity. For issuers, the bond is a safe securities because of the cost of emissions is cheaper than stocks. Besides the bond issuance also to avoid bad ratings investor than if the company issuing new shares Husnan (2007). PEFINDO assessment of the factors that determine the high bond ratings is the company's financial condition and business risk profile. Return on assets (ROA) is a profitability ratio that measures a company's ability to generate earnings from assets that were used.ROA can assist management and investors to see how well a company is able to manage its investment assets into profit or profit (profit). In addition to the rating agency, the performance of a company must also be assessed to see if the company is unable to repay its obligations. To assess the performance of the company from the inside, it takes a control instrument better known as GCG or (GCG). Implementation in the implementation of good corporate governance or corporate governance can give

* Corresponding author. Email address: dinaesensia@gmail.com 
confidence in the return of the return on investment, especially for investors and creditors. With the implementation of good corporate governance that improve the performance of the company as a whole, then this will also have an impact on the financial condition of the company's balance sheet will be better and leads to a positive direction.

Of the few differences of research results and phenomena, it can be concluded that not all the phenomena that occur in accordance with the existing scientific logic. Therefore, researchers interested in studying and learn again about this matter further. In this study, researchers added a free variable that can distinguish this study with previous research. Therefore, researchers raised a study entitled "Effect of Financial Performance And Good Corporate Governance Against Bond Ratings ".

Based on the data that has been analyzed is found that the return on assets have no significant negative effect on bond ratings and good corporate governance have a significant positive effect on bond ratings.

Furthermore, the explanation in this article will be divided into three parts, the first is a literature review that will explain any theory used in this study and previous research that referenced researcher. The second part is the results and discussion will explain the results of research and discussion of results have been found. Then, the third part is the conclusion that a more concise outline of the research study.

\section{Literature Review Signaling Theory}

Signal theory suggests how should a company give a signal to users of financial statements. These signals in the form of information about what has been done by the management to realize the wishes of the owner. Signals can be either promotional or other information which states that the company is better than any other company. Information for the provision of the published rating of the bonds expected to be a signal the company's financial condition and illustrates the possibilities that occurred in relation to debts owed. According Prog et al (2008: 214) signaling theory suggests how should companies give a signal to the users of financial statements. Information for the provision of the published rating of the bonds expected to be a signal the company's financial condition and illustrates the possibilities that occurred in relation to debts owed. One type of information released by the company that can be a signal to parties outside the company, especially for investors is the annual report.

\section{Theory Agency (Agency Theory)}

Agency theory explaining that the individual who runs an entity has the motivation caused by self-interest, giving rise to a conflict of interest between the principal (owner) and agent (manager). This theory was first proposed by Jensen and Meckling (1976), which explains that the separation of ownership with control of an entity or company. Such separation has a contractual relationship between the parties with the other party, which the owners do contract tied to the manager (agent) to perform operations of the entity for the benefit of owners with their specific delegation of authority so that managers can make informed decisions. One reason for the good corporate governance is when the shareholders or stakeholders have an interest to get the maximum profit, while the manager of the company also wants to get the wages and bonuses as much as possible to the manager of the company. The existence of two participants were led to issues about the mechanism should be established to harmonize the interests of the bebeda them both.

\section{Effect of Financial Performance Against Bond Ratings}

Profitability is a ratio showing how the company's ability to generate profits. Investments in bonds directly was not affected by the profitability of the company, for any amount of profit that can be produced by the company, bondholders still receive 
Effect of Financial Performance and Good Corporate Governance of Bond Ratings (A Case Study Companies Listed In Indonesia Stock Exchange Period 2013-2017)

the interest rate that has been determined. But analysts remain interested in the profitability of the company as this is the only best indicator of the financial health of the company Almilia, et al. (2007). According to research conducted by margreta \& Nurmayanti (2009) found that the predictive variables affect the profitability of bond ratings which means that the profitability can provide a signal to investors regarding the rating of the bonds in a company.

Profitability can be used as a complement to the analysis of risk, due to the ability of companies generate profits reflects the ability of companies obtain cash inflows. High profitability companies will gain a good cash inflows, thus reflecting a smaller risk that a better bond ratings. Based on the analysis and findings above, the research hypothesis is formulated as follows:

H1: Suspected Return On Asset affect the bond ratings

\section{Effect of Good Corporate Governance on Bond Ratings}

Husnan (2003) in the Northern (2016) states that one of the forms of funding that can be done by a company to finance its investment is by issuing bonds. Bonds not only used as a means of expansion can also be used as a means to strengthen the capital for the company. Bond rating is an indicator of the possibility of interest payments and debt on time in accordance with an agreed arrangement.

Research Asbaugh et al. (2004) in the Northern (2016) showed that companies with strong corporate governance appears to have a higher credit ratings than companies with weak corporate governance. The credit rating will affect the perception of the creditors and potential creditors on the credibility and the company's ability to meet its financial obligations as a whole..

Mariana (2016), in her study "Effects of Good Corporate Governance Mechanism against Ranked bond listed on the Indonesia Stock Exchange Period 20082010". Research shows that the proportion of independent board significant effect on bond ratings. This study did not prove that institutional ownership, insider ownership, audit committee and board size significantly affect the bond ratings. Dewi, et al. (2016), in her study "Effects of Good Corporate Governance, Profitability, Liquidity and Solvency against bond rating. The study found that good corporate governance which is proxied by corporate governance perception index positive effect on bond ratings. Based on the analysis and findings above, the research hypothesis is formulated as follows:

H2: Suspected Good Corporate Governnace affect the bond ratings.

\section{Research Methods}

Data used for this research is secondary data is data obtained indirectly. Secondary data in this study a report data that has been provided or published. Source of research data obtained memalui annual financial statements and the entire company sample that has been audited and publicized through the website of Indonesia Stock Exchange is www.idx.co.id.

The population used in this study are all manufacturing companies listed on the Stock Exchange 2013-3017 period, which amounts to 144 companies.

The sampling technique in this penlitian is purposive sampling population that has to meet certain criteria required by researchers. The criteria chosen by the researchers are:

1. Companies listed in Indonesia Stock Exchange in the period 2013-2017.

2. Companies that issue bonds and listed in Indonesia Stock Exchange in 2013-2017.

3. Companies that publishes financial statements and annual reports are complete and successively during the period 2013-2017.

Of the 555 companies listed on the Stock Exchange, which meet the criteria of the sample in this study amounted to 57 companies. 


\section{Indicators Operational Definitions and Variables}

In this study determined three variables to be studied the financial performance, good corporate governance, and the bond rating.

\section{Financial performance}

defined as the achievement of financial management, to achieve the goal of the company is generating profits and enhance shareholder value. The financial performance in this study measured using profitability ratios or in proxy by ROA.

\section{Good Corporate Governance (GCG)}

Implementation of GCG can increase the value of the company, due to the implementation of good corporate governance can reduce the risk that may be undertaken by the council with decisions that benefit themselves, and general corporate governance can increase the level of investor confidence. Newell and Wilson (2002) In this study, a proxy used to assess corporate governance are scores of Corporate Governance Perception Index (CGPI) of IICG.

\section{Bond ratings}

Bond ratings are opinions about the feasibility of the obligor on certain debt securities. Of bond ratings are expected to provide clues and input for potential investors about the quality of the bond investment interest to them. In announcing the bond rating is issued PEFINDO can be done every month. In this study, using the rating of the bonds issued by PT. PEFINDO at the end of the year ie on 31 December.

\section{Data analysis method}

The data in this study using logistic as dependent variables reflect choices among alternatives (investment grade) ratings are investment grade that have default risk is low and (non-investment grade) ratings are not worth the investment that has a bond default risk (risk of default) tall one. This model was chosen because it wanted to quantify the relationship between probability variables with a few other variables.

\section{Results and Discussion}

\section{Descriptive statistics}

Provide a picture or a description of the data visible than the minimum, maximum, average (mean), standard deviation of each variable used in this study.

Table 1 Descriptive Statistics

\begin{tabular}{cccccc}
\hline Variables & N & \multicolumn{2}{c}{ Minimum Maximum } & Mean & Std. Deviation \\
\hline ROA & 285 & -24.48 & 20.49 & 3.7500 & 4.14060 \\
GCG & 285 & 37.81 & 93.80 & 69.6314 & 8.32220 \\
Valid N (listwise) & 285 & & & & \\
\hline
\end{tabular}

Source: Data processed (2019)

\section{Feasibility Model (Goodness of Fit Test)}

Basis for a decision is to compare the value of probability with a significance level $(0.05)$. If the probability value $>0.05, \mathrm{H} 0$ is accepted, otherwise if the probability value $<0.05 \mathrm{H} 0$ is rejected.

Table 2 Hosmer and Lemeshow Test

\begin{tabular}{cccc}
\hline Step & Chi-square & Df & Sig. \\
\hline 1 & 8643 & 8 & .373 \\
\hline \multicolumn{4}{c}{ Source: Data processed (2019) }
\end{tabular}


Effect of Financial Performance and Good Corporate Governance of Bond Ratings (A Case Study Companies Listed In Indonesia Stock Exchange Period 2013-2017)

Table 2 shows that the probability value of 0.373 is greater than the significance level (0.05) H0 is accepted. This may imply that the model accepted and unfit for further analysis, because there is no real difference between the predicted classification and classification were observed.Or it can be said that the model is able to predict the value of his observations. Thus, the regression model viable for use in subsequent analyzes.

\section{Test The coefficient of determination $(\mathbf{R} 2)$}

Based on Table 3 known values of determination coefficient of 0.126 this means is that the percentage of influence vaiabel roa and good corporate governance to the bond rating is $12.6 \%$. While the rest of $87.4 \%$ diperngaruhi by other variables not included in this model. But keep in mind that the value is only a form of approach because of logistic regression coefficient of determination can not be calculated like the regression.

\begin{tabular}{cccc}
\hline \multicolumn{3}{c}{ Table 3 Model Summary } \\
\hline \multirow{2}{*}{ Step } & $\mathbf{- 2}$ log & Cox \& Snell R & Nagelkerke R Square \\
likelihood & Square & .126 \\
\hline & $213.821 \mathrm{a}$ & .071 & \\
\hline
\end{tabular}

Source: Data processed (2019)

\section{Classification matrix}

Based on the classification matrix table above, shows that the predictive power of the regression model to predict the likelihood of investment grade companies amounted to $98.4 \%$. This means that by using regression models were used turned out to be as many as 240 companies $(98.4 \%)$ were predicted to investment grade. Meanwhile, the predictive power of the model non-investment grade companies was $2.6 \%$ which means that the regression model is used there are two companies $(2.6 \%)$ were predicted to non-investment grade. The explanation is based on the overall percentage of $87 \%$, which means the accuracy of the model of this study was $84.9 \%$.

Table 4 Table Classification

\begin{tabular}{|c|c|c|c|c|}
\hline & \multirow[b]{2}{*}{ Observed } & \multicolumn{2}{|c|}{$\begin{array}{l}\text { Predicted } \\
\text { Bond rating }\end{array}$} & \multirow[b]{2}{*}{$\begin{array}{l}\text { Percentage } \\
\text { Correct }\end{array}$} \\
\hline & & $\begin{array}{c}\text { Non } \\
\text { Investment } \\
\text { Grade }\end{array}$ & $\begin{array}{c}\text { Investment } \\
\text { Grade }\end{array}$ & \\
\hline \multirow{4}{*}{ Step 1} & Non & & & \\
\hline & Bond Investment & 2 & 39 & 4.9 \\
\hline & $\begin{array}{c}\text { Rating } \begin{array}{c}\text { Investment } \\
\text { Grade }\end{array}\end{array}$ & 4 & 240 & 98.4 \\
\hline & Overall Percentage & & & 84.9 \\
\hline
\end{tabular}

\section{Overall Test Model (Overal Model Fit Test)}

The existence of deterioration in value between $-2 \log$ likelihood beginning with a value of $-2 \log$ likelihood in the next step shows that the hypothesized model fits the data. Decrease Log Likelihood models showed a regression model that better Santoso (2017). 
Table 5 Iteration History a, b, c

\begin{tabular}{|c|c|c|c|}
\hline \multicolumn{2}{|c|}{ iteration } & $\begin{array}{c}-2 \text { log } \\
\text { likelihood }\end{array}$ & $\frac{\text { Coefficients }}{\text { Constant }}$ \\
\hline \multirow{4}{*}{ Step 0} & 1 & 239710 & 1,425 \\
\hline & 2 & 234841 & 1,745 \\
\hline & 3 & 234788 & 1,783 \\
\hline & 4 & 234788 & 1,784 \\
\hline
\end{tabular}

Table 6 Iteration History a, b, c

\begin{tabular}{cccccc}
\hline \multirow{2}{*}{ iteration } & \multirow{2}{*}{$\begin{array}{c}2 \text { log } \\
\text { likelihood }\end{array}$} & \multicolumn{3}{c}{ Coefficients } \\
\cline { 3 - 6 } & & & Constant & ROA & GCG \\
\hline & 1 & 224.379 & -1.458 &,- 032 &, 043 \\
& & & & & \\
Step 1 1 & 214.236 & -2.735 &,- 054 &, 069 \\
& 3 & 213.823 & -3.041 &,- 062 &, 075 \\
& 4 & 213.821 & -3.056 &,- 062 &, 075 \\
& 5 & 213.821 & -3.056 &,- 062 &, 075 \\
\hline \multicolumn{3}{c}{ Source: Data processed (2019) } \\
\end{tabular}

Table 7 Log Likelihood

\begin{tabular}{ccc}
\hline Block Number Beginning & Block Number End & Decrease / Increase \\
\hline 234.788 & 213.821 & reduction \\
\hline \multicolumn{3}{c}{ Source: Data processed (2019) }
\end{tabular}

Based on the initial value table 5 -2 Log Likelihood of 234.788 and $-2 \log$ Likelihood final value in Table 6 is equal to 213.821. The decline between $-2 \mathrm{Log}$ Likelihood initial value and final value of $-2 \log$ Likelihood indicate that the regression model, the better.

\section{Simultaneous Test (Test F)}

Table 8 Omnibus Tests of Model Coefficients

\begin{tabular}{lcccc}
\hline & & Chi-square & Df & Sig. \\
\hline Step 1 & Step & 20.966 & 2 &, 000 \\
& Block & 20.966 & 2 &, 000 \\
& Model & 20.966 & 2 &, 000 \\
\hline \multicolumn{4}{c}{ Source: Data processed (2019) }
\end{tabular}

Based on table 8 diketahui Chi Square value of 20.966 with a significance of 0.000 . Because the significance value $(0.000)<0.05$. Means that the ROA and GCG jointly significant effect on bond ratings,

\section{Partial Test (Test T)}

In Santoso (2017) regression coefficient test was conducted to test how far all independent variables included in the model have an influence on the dependent variable. Regression coefficient test value can be seen from Table Variables in the Equation, to see the value in the column signfikansi.Decisions concerning acceptance or rejection of H0 can be done in the following way Santoso, (2017): 
Effect of Financial Performance and Good Corporate Governance of Bond Ratings (A Case Study Companies Listed In Indonesia Stock Exchange Period 2013-2017)

$\mathrm{H} 0: \beta 1=0$ then the regression coefficient is not significant

$\mathrm{H} 1: \beta 1 \neq 0$ then a significant regression coefficient

Then the value of profitability in table Variables in the Equation compared with the significance level of 0.05 . If the probability value $>0.05, \mathrm{H} 0$ is accepted and if the probability value $<0.05 \mathrm{H} 0$ is rejected. At 5:10 table presented value Variable In The Equation.

Table 9 Variables In The Equation

\begin{tabular}{cccccccc}
\hline & & B & SE & Wald & Df & Sig. & $\operatorname{Exp~(B)~}$ \\
\hline \multirow{3}{*}{ Step 1a } & ROA &,- 062 &, 042 & 2,198 & 1 &, 138 &, 940 \\
& GCG &, 075 & .019 & 15.391 & 1 &, 000 & 1,078 \\
& Constant & -3.056 & 1,333 & 5.251 & 1 &, 022 &, 047 \\
\hline \multicolumn{7}{c}{ Source: Data processed (2019) }
\end{tabular}

1. Based on Table 4 found that the variable return on assets (ROA) with a regression coefficient,- 062 has a probability value of $0.138>0.05$. What this means is that the ROA no significant effect on bond ratings.

2. 5:10 According to the table found that the variable good corporate governance (GCG). the regression coefficient, 075 has a probability value of $0.000<0.05$. What this means is that GCG significant effect on bond ratings.

\section{Financial Performance Probability Influence on Bond Ratings}

Under the table 9 it is in indication that companies that have a high ranking or better, then the probability of the company itself to get a better rating also increased. Companies are well worth the investment to the level of investment kelayak is worthy of investment (investment grade) were given a score of 1 to the ratings categories, namely: idAAA, AA, idA and idBBB. And not worth the investment (non invesmnet grade) were given a score of 0 and ranked category idBB, IDB, CCC, SD, D. When a company is able to manage its assets efficiently, the company produces high ROA, so that the probability of a company's worth the investment to investment grade bond ratings. The indication is for the investor needs to pay attention to the company that has a good rating so that the company is worth to invest.

The results showed that the return on assets significant negative effect on the probability of bond ratings. ROA in this case shows the company's ability to generate profits. With high ability to generate profits, then the company can improve its ranking and can convince investors to buy bonds issued by the company. Adams et al. (2000) mengemukanan that the high level of profitability will show strong financial condition of companies that financially affect bond ratings, but the results of this study indicate that profitability negatively affect bond ratings, which means ROA high does not guarantee a bond to get a high rating from agency the rating of the bonds. although the company earned high profits, but profits that companies use to pay short-term obligations and long term, and a decrease in the level of profitability is likely due to higher cash outflows in each of these companies, and not significant means to lower or decrease the value of ROA an enterprise does not give effect to the bond rating. so the profitability variable alone can not be used to assess the bond rating, but there are other factors that can be used for bond ratings.

This is not in line with signaling theory which says that the signal will be delivered by the manager to the market that the company has good prospects in the future in order for the company's shares rose and investors' hopes capturing these signals because the management is committed to increasing the value of the company so as to increase bond rating company.Profitability measures the company's ability to 
generate profits based on a specific asset level. The higher profit generated more profit is expected the company's ability to meet its obligations, the better away from default risk. High levels of profitability which can indicate the ability of the company's going concern and demonstrates the company's ability to meet its obligations. The higher the bond rating provides a signal that the probability of the risk of failure in fulfilling obligations lower. This is in line with research Satoto (2011) who studied the ability of Financial Ratio as a Tool for Predicting Bond Ratings, which indicates that ROA no significant effect on bond ratings.

\section{Effect of Good Corporate Governance of the probability of Bond Ratings}

Based on the research results indicate that good corporate governance is a significant positive effect on the probability of bond ratings. It can be concluded that good corporate governance directly affect the bond ratings. This means that if a company has good corporate governance it will affect the bond ratings announcement, which the bond rating would indicate classification good value, otherwise if governance kekola a bad company then the company will announce a low rating.

Currently the business actors such as investors, lenders, and stakeholders increasingly realize the importance of good corporate governnace implementation within the company due to increased competition and globalization conditions. It dikarenkan good corporate governance is one of the important factors in assessing the performance of a sufficiently firm. good corporate governance of the company the better the performance of a company. In addition, the implementation of GCG implementation within a company is a big opportunity for the company to achieve a variety of benefits, including confidence in the company. As in the theory of agency good corporate governance appears as an attempt to control the behavior of management to act in the interests of each as well as a control tool to allow terciptnya system of profit sharing and wealth balance.

This is consistent with agency theory emphasizes the importance of delegation of authority from the principal to the agent, where the agent has an obligation to manage the company in accordance with the interests of the principal. By implementing good corporate governance circuitry refers to the principle and guidelines become one of the ways that can be used to minimize the occurrence of discrepancies between the principal and the agent within a company or organization. Therefore required implementation of good governance at the company. The better the implementation of good corporate governance of a company, the better the bond rating announcement on each company. This is in line with research Dewi \& Yasa (2016) which shows that Corporate Governance index positive effect on bond ratings.

\section{Conclusion}

Return On Asset have no significant negative effect on the rating and Good Corporate bonds have significant positive effect on bond ratings. Suggested for further research, is expected to retest the other factors more diverse and add the variables that can affect the bond ratings. It is intended that the conclusions that have wider coverage anyway. For a company of this research can be used as a material consideration to evaluate, improve and enhance the company's financial performance in the future this research datang.Bagi potential investors can be expected as a material consideration and be a warning signal before investing.

\section{References}

Adams, M., Burton, B., \& Hardwick, P. (2000). The Determinants of Credit Ratings in the United Kingdom Insurance Industry. Journal of Accounting and Economics, 19. 
Effect of Financial Performance and Good Corporate Governance of Bond Ratings (A

Case Study Companies Listed In Indonesia Stock Exchange Period 2013-2017)

Almilia, L. S., \& Devi, V. (2007). Factors that Pempengaruhi Prediction Bond Ratings in Manufacturing Companies Listed on the Jakarta Stock Exchange.

Amrullah, K. (2007). The ability Financial Ratio as a Tool for Predicting Bond Ratings Manufacturing Company. [Thesis]. Semarang: Unnes.

Daniri, M. A. (2005). Good Corporate Governance: Concepts and Practice in the Context of Indonesia. Jakarta: Indonesian Ray.

Dewi, K. K., \& Yasa, W. G. (2016). Effect of Good Corporate Governance, Profitability, Liquidity and Solvency against bond rating The Indonesian stock exchange. Journal of Economics, Business and Entrepreneurship, 6(1), 59- 70.

FCGI (Forum For Corporate Governance In Indonesia). nd role of the Board of Commissioners and the Audit Committee in Implementing Corporate Govenance (GCG). Series of Corporate Governance (Corporate Governance) Volume II.

Ghozali, I. (2016). Applications Multivariate Analysis with SPSS. Semarang: Diponegoro Publisher Agency.

Ginting, S. (2012). Influence Analysis of Cash Flow Growth And Profitability Return Of Shares In The Company Lq 45 in Indonesian Stock Exchange. Journal of Economic Wira Mikroskil, 2(1).

Hartono, J. (2008). Portfolio Theory and Investment Analysis ( $5^{\text {th }}$ Edition). Yogyakarta: BPFE

Husnan, S. (2007). Financial Management Theory and Application (Long-Term Decision). Yogyakarta: BPFE.

Jensen, M. C., \& Meckling, W. H. (1976). Theory of the Firm: Managerial Behavior, Agency Costs and Ownership Structure. Journal of Financial Economics, 3, 305560 .

Magreta., \& Nurmayanti, P. (2009). Factors Affecting Prediction Seen From Bond Ratings in Accounting Factors and Non-Accounting. Business and Accounting Journal, 11(3), 143-154.

Mariana. (2016). Effect of Good Corporate Governance Mechanism against Ranked bond listed on the Indonesia Stock Exchange Period 2008-2010.

Newell, R., \& Wilson, G. (2002). A premium for good governance. The McKinsey Quartely, 3, 20-23.

Rahardja., \& Sari, M. P. (2008). Comparative Analysis Tool (Discriminant and Logistic Regression) on Bond Ratings.

Santoso, S. (2017). Multivariate Statistics with SPSS. Jakarta: PT. Elex Media Komputindo.

Satoto, S. H. (2011). Analysis of Factors Affecting Bond Rating. Karisma, 5(2), 104115.

Weston, J. F., \& Brigham, E. (1994). Fundamentals of Financial Management. Bandung: Erland

www.idx.com Retrieved on September 17, 2018.

www.pefindo.com Retrieved on September 15, 2018. 